\title{
FAKTOR DEMOGRAFI DALAM STRATEGI ELEKTORAL PILKADA: PERSPEKTIF DARI LAPANGAN
}

\author{
Kuskridho Ambardi \\ Departemen IImu Komunikasi dan Departemen Politik dan Pemerintahan, Fisipol, Universitas \\ Gadjah Mada dan Lembaga Survei Indonesia \\ Korespondensi: Kuskridho Ambardi (e-mail: ambardi5000@yahoo.com)
}

\begin{abstract}
Abstrak
Di tengah merebaknya analisis post-demographics lima tahun terakhir di Indonesia, analisis demografi tetap menjadi potongan penting untuk memahami politik pilkada. Artikel ini akan mendemonstrasikan bahwa di gelanggang pilkada, para kandidat secara intuitif memanfaatkan faktor-faktor demografis dalam strategi pencalonan kepala daerah dan memobilisasi dukungan politik untuk memenangi kompetisi politik di tingkat lokal. Namun, tidak semua faktor demografi dan isu-isu yang berbasis demografi dimanfaatkan dalam penyusunan strategi elektoral tersebut. Isu yang berkaitan dengan status migran, agama, kesukuan, dan kedaerahan adalah isu yang kerap dieksplorasi dan dieksploitasi. Untuk memobilisasi kelompok-kelompok demografis ini, para kandidat lebih banyak melakukan kampanye yang tidak berbasis isu kebijakan. Akibatnya, isu-isu primordial lebih banyak tampil di gelanggang pilkada ketimbang isu-isu kebijakan. Dalam jangka pendek, pemetaan politik konvensional yang berbasis pada klasifikasi demografi akan tetap berjalan. Akan tetapi, untuk jangka panjang, pemetaan dan analisis post-demographic akan menjadi saingan dalam bisnis jasa pemetaan politik di pilkada.
\end{abstract}

Kata kunci: demografi, strategi kampanye, primordialisme

\section{DEMOGRAPHIC ANALYSIS IN INDONESIAN LOCAL ELECTIONS: A VIEW FROM THE BATTLEFIELDS}

\begin{abstract}
Demographic analysis is an important part of electoral strategies. This paper will show that electoral candidates in Indonesian local elections intituitively make use of demographic mapping for formulating their electoral strategies to win the elections. However, they purposefully and selectively target only a set of particular demographic groups that provide them electoral gains while ignoring others. Religious, ethnic, and migrant divisions are seen as more important electorally than gender and rural-urban divisions. To mobilize these groups, they tend to develop non-policy-based or symbolic campaigns instead of formulating policy-based campaigns. As a result, in local elections, primordial issues are more prominent than policy issues. In the short run, demographic analysisis will stay as the main strategic electoral tool for these candidates. In the long run, however, this mode of analysis will have to compete against post-demographic modes of analysis that have started to gain traction among national and local politicians.
\end{abstract}

Keywords: demography, campaign strategy, primordialism 


\section{Pengantar}

Data demografi adalah jantung pemilu dan pilkada. Dari sudut penyelenggara pemilu, data demografi tentang jumlah populasi dan jumlah pemilik hak suara adalah isu yang sangat penting, sebab perhitungan jumlah populasi itu akan menjadi basis pendataan administrasi dan perencanaan logistik penyelenggaraan sebuah pemilu. Selain itu, isu demografi juga memiliki nilai strategis secara politik. Data demografi yang akurat dan terpercaya akan memberikan legitimasi politik yang kuat pada para pemimpin politik yang memenangkan kompetisi politik melalui pemilu. ${ }^{1}$

Dari sudut para peserta pemilu, data demografis memiliki nilai strategis lain. Informasi demografis akan memberikan basis pemetaan politik dalam merancang strategi elektoral untuk memenangi pemilu. Tanpa data komposisi demografi pemilih, partai politik dan para kandidat peserta pemilu akan memboroskan dana karena kesulitan mengidentifikasi target kampanye secara efisien. Tanpa tersedianya data komposisi demografis pemilih, para peserta pemilu akan gagal menggali isu-isu permasalahan sosial yang dihadapi berbagai kelompok sosial yang ada dalam masyarakat. Tanpa data-data tersebut, mustahil bagi mereka merumuskan isu-isu kebijakan spesifik yang cocok untuk berbagai kelompok pemilih yang akan memberikan suara dalam pilkada.

Di lapangan, sejauh mana isu-isu yang berbasis demografi menjadi isu penting dalam pertarungan di politik pemilu Indonesia? Bagaimana para kandidat dan tim kampanye di berbagai gelanggang pilkada menggunakan data demografis untuk memenangi pilkada?

\footnotetext{
1 Permasalahan yang bersumber dari rendahnya kualitas DPT yang disediakan KPU atau KPUD sering memunculkan gugatan dari kandidat dan publik. Contoh penting muncul pada kasus DPT Pemilu Presiden 2009 ketika dua pasangan kandidat yang kalah pemilu mengajukan gugatan ke Mahkamah Konstitusi atas tuduhan keteledoran KPU dalam menyiapkan DPT. Lihat bagian selanjutnya.
}

Bagaimana mereka mengidentifikasi target kampanye untuk menggali peta permasalahan sosial yang menjadi perhatian berbagai kelompok sosial dan untuk merumuskan isu-isu kebijakan spesifik yang berbasis kepentingan kolektif kelompok-kelompok demografis? Bagaimana implikasi teoretis dari strategi elektoral dan taktik kampanye yang dijalankan para kandidat di gelanggang pilkada? Tidak kalah penting, pola-pola apa saja yang muncul dalam strategi kampanye yang berbasis demografi di pilkada-pilkada itu dan bagaimana implikasi etisnya terhadap kualitas praktik demokrasi di tingkat lokal? Terakhir, sejauh mana analisis demografis ini tetap bermanfaat di tengah-tengan munculnya faddism baru, yakni analisis postdemographics?

Artikel ini akan mengeksplorasi jawaban atas sejumlah pertanyaan di atas dengan mendemonstrasikan beberapa hal. Pertama, isu demografis masih menyisakan pekerjaan rumah bagi Pemerintah Indonesia meskipun sensus kependudukan telah dilakukan secara reguler dalam siklus sepuluh tahunan. Kedua, banyak elite lokal memiliki kesadaran dan kepekaan untuk memanfaatkan datadata demografis dalam merancang strategi elektoralnya. Ketiga, dengan cerdik, sejumlah elite lokal memanfaatkan dan memilih isu-isu berbasis demografi yang memiliki dampak elektoral lebih besar dalam kampanye mereka, sedangkan pada saat yang sama mereka mengabaikan isu-isu demografis yang kecil efek elektoralnya atau bahkan mengabaikannya sama sekali. Keempat, mode pemanfaatan isu-isu demografis secara selektif tidak selalu membawa efek yang bagus bagi peningkatan kualitas demokrasi di tingkat lokal, khususnya dalam upaya meluaskan jumlah pemilih rasional di berbagai wilayah.

Sebuah catatan perlu disampaikan di sini. Artikel ini tidak menyajikan dan menguji serangkaian tesis tentang efek faktor demografi terhadap preferensi politik pemilih dalam pilkada meskipun isu-isu ini tidak 
dapat dihindari dalam diskusi nanti. Artikel ini memberikan tinjauan dari lapangan, yakni sebuah upaya untuk memahami cara kerja faktor-faktor demografis dari sudut pandang para aktor politik dalam gelanggang riil pilkada. Kemudian pada bagian epilog artikel ini akan menimbang implikasi teoretis dan etis dari strategi elektoral para kandidat di pilkada terhadap peningkatan atau penurunan kualitas demokrasi di tingkat lokal.

\section{Politik Demografi}

Secara umum, studi demografi sering didefinisikan sebagai studi tentang ukuran, struktur, dan distribusi populasi di sebuah wilayah serta perubahan-perubahannya yang disebabkan oleh peristiwa kelahiran dan kematian, proses penuaan, dan peristiwa migrasi. $^{2}$ Metode yang digunakan untuk melakukan pengukuran dan analisis pun melibatkan istilah dan kerja teknis yang rumit dan kompleks. Jika melihat definisi standar tersebut, demografi memberikan sebuah anasir yang netral dan terkesan teknokratis yang jauh dari hingar-bingar politik.

Gambaran sebaliknya justru tampak pada ilustrasi kasus Myanmar. Sensus kependudukan Myanmar tahun 2014 yang penyelenggaraannya ditopang UN Population Fund dan memakan dana besar sarat dengan bobot politik. Sensus tersebut memperbarui data kependudukan Myanmar yang telah kedaluwarsa sejak sensus terakhir pada 1983. Untuk satu hal, sensus tersebut memperbaiki akurasi jumlah populasi Myanmar. Semula populasi Myanmar diperkirakan dapat mencapai 70 juta, tetapi setelah sensus dilakukan, jumlah tersebut terkoreksi menjadi 51,5 juta penduduk saja. Dalam proses pelaksanaan sensus, kontroversi berputar pada pertanyaan yang berkaitan dengan identitas kesukuan para warga.

\footnotetext{
${ }^{2}$ Lihat, antara lain, Dudley Poston Jr, Dudley and Leon Bouvier. 2010. Population and Society: An Introduction to Demography. New York: Camridge University Press.
}

Petugas sensus membawa sebuah daftar yang berisi jenis suku di Myanmar yang terdiri atas 135 kelompok suku dan meminta setiap wajib sensus untuk memilih satu kategori identifikasi keanggotan kesukuan. Daftar ini bermasalah karena tidak melewati proses konsultasi dengan suku-suku minoritas yang totalnya mencapai proporsi 40 persen dan mereka merasa dirugikan (The Economist, http://www.economist. com/news/asia/21599404-ill-consideredheadcount-stirs-anger-and-mistrust-toomuch-information). Suku Chin, misalnya, dibelah dalam sejumlah subetnis yang lebih kecil sehingga secara numerik, kelak suku ini akan lemah ketika melakukan tekanan politik karena suku itu menjadi terpecah dalam jumlah yang kecil-kecil. Sementara itu, pertanyaan tentang identitas suku ini membawa permasalahannya tersendiri dalam konteks politik etnis di Myanmar. Sejumlah warga tidak merasa nyaman untuk membuka identitas kesukuannya karena takut kelak hak-hak politik mereka akan terpangkas yang disebabkan oleh status mereka yang minoritas (The Economist, http://www.economist. com/news/asia/21599404-ill-consideredheadcount-stirs-anger-and-mistrust-toomuch-information). Lebih jauh lagi, bahkan mereka mengkhawatirkan akan diperlakukan sebagai "orang asing" yang tidak memiliki hak suara karena jenis etnisitas mereka tidak berada dalam daftar sensus. Ini terjadi pada para warga Myanmar keturunan Asia Selatan. Eksklusivitas ini pun dialami oleh kelompok etnis Rohingya yang tinggal di wilayah yang berdekatan dengan Bangladesh.

Problem ini bertemu dengan praktik malapportionment atau praktik penjatahan kursi yang diperebutkan untuk memasuki majelis rendah parlemen (lower house) melalui pemilu. Penjatahan kursi di majelis itu didasarkan pada unit township atau unit kota ketimbang unit populasi. Akibatnya, pemilih yang tinggal jauh dari perkotaan mengalami proses penghilangan hak suara mereka tidak dapat menggunakan suaranya. 
Celakanya, banyak etnis minoritas yang tinggal di daerah-daerah pinggiran sehingga mereka tidak mendapatkan kursi perwakilan di majelis rendah parlemen. ${ }^{3}$

Dalam perbandingan, Indonesia tidaklah memiliki dan mengalami problem seburuk Myanmar dalam urusan data demografi. Hal ini mengingat sensus kependudukan di Indonesia dijalankan secara reguler setiap sepuluh tahun. Pemutakhiran data pemilih yang berbasis populasi dilakukan setiap menjelang pemilu, bahkan proses ini dijalankan di tingkat lokal menjelang berlangsungnya pilkada. Namun, sejumlah persoalan yang mirip juga bermunculan di Indonesia, baik pemilu nasional maupun pemilihan kepala daerah (pilkada).

Tahun 2009 gugatan publik dan peserta pemilu presiden menjadi tajuk berita di media massa untuk waktu yang panjang, bahkan sebelum dan sesudah pilpres diselenggarakan. Inti gugatannya adalah kualitas Daftar Pemilih Tetap (DPT) yang disusun oleh Komisi Pemilihan Umum menjelang pemilu presiden dianggap begitu buruk sehingga banyak pemilih (berpotensi) kehilangan hak suaranya. Lebih spesifik lagi, gugatan publik yang dikirimkan ke Mahkamah Konstitusi menyoal banyaknya pemilih yang tercatat dua kali dalam DPT, sedangkan masih banyak yang tidak tercantum di daftar tersebut. Untuk itu, pihak penggugat memohon kepada MK agar membatalkan Pasal 111 (1) UU No. 42/2008 tentang Pemilu Presiden yang menyatakan bahwa pemilih yang berhak mengikuti pemungutan suara di Tempat Pemungutan Suara (TPS) adalah pemilih yang terdaftar di DPT asli dan/atau DPT tambahan (http://www.hukumonline. com/berita/baca/lt4b3c5d4990d94/kisruh-dpt-

\footnotetext{
3 Lihat,http://foreignaffairsreview.co.uk/2015/11/ democracy-in-myanmar/. Lihat juga sumber domestik di Myanmar di http://www.irrawaddy.com/election/feature/ in-burma-not-all-votes-are-created-equal. Judul analisis yang tajam "In Myanmar, Not All Votes Are Created Equal" merefleksikan cacat bawaan data demografis dan pilihan sistem elektoral Myanmar yang sulit diterima untuk sebuah kualitas praktik demokrasi yang standar.
}

noda-tercecer-di-pemilu-2009). Kalau pasal ini tidak dihapus atau direvisi, maka banyak pemilih yang akan kehilangan hak suaranya karena waktu perbaikan DPT terlalu pendek.

Setelah pilpres, Megawati Soekarnoputri dan Prabowo Subianto mengajukan gugatan berikutnya ke MK. Isi gugatannya terhadap KPU merujuk pada problem kualitas DPT yang sama, yakni menganggap KPU secara "sengaja atau setidak-tidaknya lalai dalam penyusunan DPT" dan KPU "sengaja atau setidak-tidaknya lalai menindaklanjuti temuan pasangan calon ataupun masyarakat, bahkan Banwaslu terkait penyusunan DPT." Dua poin gugatan ini masih ditambah dengan gugatan lain, yakni KPU dianggap sengaja menghilangkan 69 ribu TPS yang berpotensi pula menghilangkan sekitar 34,5 juta suara pemilih. Dengan itu, pemohon atau pihak penggugat mengimplikasikan bahwa hasil penghitungan suara Pemilu Presiden 2009 tidak sah.

Untuk gugatan yang pertama, MK mengabulkan sebagian dengan mengeluarkan putusan bahwa para pemilih dapat dan boleh menggunakan kartu identitas pribadi ketika memberikan suaranya di TPS. Dengan demikian, para pemilih tidak lagi semata tergantung pada DPT untuk memberikan suaranya. Sementara itu, untuk gugatan kedua, MK membuat putusan yang bersisi ganda. Di satu sisi, MK menyatakan bahwa hasil penghitungan KPU adalah sah, tetapi pada saat yang sama MK juga menyatakan perlunya perbaikan DPT dan perbaikan regulasi yang menjadi dasar penyusunan DPT. (Putusan MK Nomor 108-109/PHPU.BVII/2009). Implikasi dari kontroversi DPT dan putusan MK yang menyertainya secara tidak langsung membenarkan adanya problem DPT dan sedikit mengoyak legitimasi hasil Pilpres

\footnotetext{
${ }^{4}$ Gugatan terhadap KPU ini tercantum dalam Putusan MK Nomor 108-109/PHPU.B-VII/2009. Tiga poin gugatan terhadap KPU ini masih ditambah dengan gugatan keempat yang tidak berkaitan dengan data DPT yang berbasis data demografi, yakni soal campur tangannya pihak asing (IFES) dalam proses tabulasi nasional penghitungan suara Pemilu Presiden 2009.
} 
2009. Kenyataannya, isu perekayasaan dan politisasi DPT tetap hidup jauh setelah pemilu usai. $^{5}$

Kedua gugatan tersebut pada permukaannya terlihat bersifat teknis dan keputusan yang dihasilkan MK dapat dianggap menyelesaikan masalah. Akan tetapi, ketika berbicara tentang DPT, sesungguhnya yang dibahas adalah pemenuhan dan penghilangan hak suara sekaligus. Hanya saja, bungkus bahasa hukum dalam gugatan, sidang, dan putusan MK tidak memberikan informasi yang lebih spesifik untuk sebuah pertanyaan: sejauh mana potensi disenfranchisement itu memiliki bias pada kelompok demografis tertentu?

Pertanyaan ini hampir mustahil untuk dijawab, sebab berbagai pemberitaan media maupun berkas perkara gugatan yang diajukan ke MK tersebut tidak memuat profil demografis para pemilih yang tidak terdaftar di DPT. Tidak tersedianya data demografis yang tersusun secara sistematis tentang potensi disenfranchisement ini menutup kemungkinan studi perbandingan problem Indonesia dengan Myanmar atau negaranegara lain. Namun, jika melihat luasnya liputan media massa tentang ketidakberesan penyusunan DPT di tingkat nasional, provinsi, kabupaten, dan kota pada pemilu 2009, besaran masalahnya terasa sangat luas.

Di tingkat provinsi, misalnya, problem ketidakberesan DPT ini ditemui di lima belas provinsi, seperti Sumatera Utara, Banten, Jawa Barat, Jawa Tengah, dan Jawa Timur (https:// koran.tempo.co/konten/2009/06/03/166937/ Daftar-Pemilih-Bermasalah-di-15-Provinsi.). Demikian juga kasus-kasus yang sama terjadi muncul di tingkat kabupaten/kota di provinsiprovinsi tersebut. Sebagai contoh adalah

\footnotetext{
5 Sebagian kalangan masih meyakini sampai beberapa tahun setelahnya bahwa kemenangan pasangan capres dan cawapres Susilo Bambang Yudhoyono dan Budiono dalam Pemilu Presiden 2009 dengan melalui rekayasa DPT. Lihat misalnya, Pan Mohamad Faiz (2016), "Dimensions of Judicial Activism in the Constitutional Decisions," https://ejournal.mahkamahkonstitusi.go.id/ index.php/jk/issue/download/32/62.
}

wilayah yang mengalami ketidakberesan DPT di Jawa Tengah, antara lain, adalah Kabupaten Boyolali, Semarang, Banyumas, dan Kota Salatiga (http://nasional.kompas. $\mathrm{com} / \mathrm{read} / 2009 / 04 / 01 / 20572617 /$ puluhan. ribu.dpt.bermasalah.di.jateng.).

Tahun 2014 kasus-kasus yang sama juga muncul di tingkat nasional dan lokal sehingga KPU menunda pengumuman DPT ke publik (http://www.bbc.com/indonesia/berita indonesia/2013/10/131023_kpu_tunda_ penetapan_dpt).

Belajar dari pengalaman ini, persoalan lama tentang DPT itu dapat muncul lagi pada pilkada yang diselenggarakan secara serentak tahun 2013 dan 2017. Jika di tingkat nasional besaran ketidakberesan DPT dapat mencapai akumulasi jutaan pemilih, maka di tingkat provinsi besaran itu lazimnya menurun dan hanya melibatkan ratusan atau puluhan ribu saja. Demikian juga besaran masalahnya menurun lagi di tingkat kabupaten dan kota yang hanya sampai jumlah ribuan atau bahkan ratusan saja. Namun, dari perspektif yang berbeda, bilangan ribuan, bahkan ratusan dapat menjadi penting dalam proses pilkada, terutama di wilayah-wilayah yang perolehan suara para kandidat hanya berselisih ribuan atau ratusan. Selisih suara yang tipis yang hanya berkisar ratusan suara ini terjadi, misalnya, di Kabupaten Bangka Barat, Kabupaten Kuantan Sengginggi, Kota Binjai, dan Konnawe Utara (http://nasional.kompas. com $/ \mathrm{read} / 2015 / 12 / 15 / 17023981 /$ Selisih. Tipis.Hasil.Pilkada.di.13.Daerah.Berpotensi. Sengketa).

Dengan melihat dua kasus tersebut, yakni kasus gugatan ke MK dan ketidakberesan DPT di pilkada, nilai akurasi DPT menjadi penting dalam dua konteks. Pertama, kecilnya jumlah populasi sebuah wilayah pilkada dan semakin kecilnya jumlah pemilih di wilayah tersebut akan semakin penting pula akurasi dalam menentukan pemenang pilkada. Kedua, semakin kompetitif sebuah pilkada - dengan dua pasangan atau lebih hanya 
memiliki selisih suara sedikit - akan semakin penting pula tingkat keakurasian DPT. Jamak bahwa para kandidat dan partai pengusung pasangan kandidat kepala daerah selalu mempersoalkan keakurasian DPT. ${ }^{6}$

Sampai di sini terlihat bahwa isu demografi dan DPT tidak hanya penting dalam urusan legitimasi dan penerimaan hasil pemilu, tetapi isu-isu tersebut juga penting dilihat dari nilai strategis elektoralnya. Pada akhirnya, pilkada harus berjalan dan DPT mau tidak mau para kandidat di gelanggang pilkada harus segera menyiapkan strategi elektoralnya untuk memenangi pilkada dengan kualitas DPT yang ada. Peta dukungan pemilih yang berbasis analisis demografis harus dilakukan.

\section{Parameter Demografi: Mana yang Lebih Penting?}

$\mathrm{Di}$ berbagai literatur standar yang menyajikan panduan kampanye, analisis demografis menjadi basis dalam merancang strategi pemenangan pemilu. ${ }^{7}$ Analisis demografis yang memilah pemilih dalam berbagai pengelompokan sosial menjadi basis penentuan target pemilih dan perumusan pesan kampanye.

Lazimnya pengelompokan dengan basis karakteristik demografi didasarkan pada sejumlah kriteria: jenis kelamin, usia, suku, agama, tingkat pendidikan, lokasi tempat tinggal, jenis pekerjaan, dan tingkat penghasilan. Sensus BPS mencatat semua komposisi demografis di tingkat nasional, provinsi, dan kabupaten atau kota. Akan tetapi, dalam konteks pilkada, tidak semua

\footnotetext{
6 Antara lain, contohnya, protes yang dilakukan oleh Malkan Amin dalam pilkada 2010 di Kabupaten Barru yang mempersoalkan keakuratan DPT sejak awal sebelum pilkada dilakukan (lihat http://www.tribunnews. com/election/2010/06/21/kisruh-dpt-di-samalewa).

7 Lihat misalnya, Michael Burton and Daniel Shea (2010, 4 $4^{\text {th }}$ edition), Campaign Craft: The Stretgies, Tactics, and Art of Political Management. Santa Barbara, California: Praeger.
}

karakteristik demografi itu sama di setiap wilayah dan dianggap memiliki bobot politik yang sama bagi para kandidat, khususnya ketika dikaitkan dengan tujuan pemenangan pemilu.

Misalnya, pembedaan lokasi tempat tinggal desa-kota tidak berlaku untuk Provinsi DKI Jakarta, sebab seluruh wilayah Jakarta termasuk kategori perkotaan. Di Kota Bontang, proporsi penduduk yang tinggal di perdesaan hanya 2,2 persen. Sementara itu, untuk sejumlah kabupaten lain, proporsi pemilih yang tinggal di perkotaan terlalu sedikit sehingga pengelompokan desa-kota menjadi kurang penting secara elektoral. Strategi pesan kampanye yang khusus dirancang untuk pemilih perkotaan hanya akan menyumbangkan sedikit saja pertambahan suara dukungan.

Hal yang sama juga terjadi pada bobot suara pemilih perempuan. Data sensus terakhir BPS tahun 2010 menunjukkan bahwa proporsi laki-laki perempuan di Indonesia mendekati seimbang 50:50. ${ }^{8}$ Di tingkat provinsi dan kabupaten/kota, variasinya sangat minimal. Oleh karena itu, secara numerik, jumlah 50 persen pemilih perempuan itu dapat mengantarkan seorang kandidat kepala daerah untuk memenangkan pilkada. Sebagaimana diketahui, ambang batas pemenangan pilkada dalam satu putaran hanyalah 30 persen, kecuali untuk DKI Jakarta yang memiliki threshold 50 persen. Persoalannya adalah kandidat perempuan dan isu-isu perempuan ternyata tidak menjamin kemenangan dalam pemilu, baik pemilu presiden maupun pilkada.

Pemilu Presiden 2004 dan 2009 diikuti oleh kandidat presiden perempuan, yakni Megawati Soekarnoputri. Namun, di dua pilpres tersebut, Megawati dan pasangan cawapresnya hanya mampu meraih proporsi

\footnotetext{
8 Secara makro, komposisi laki-perempuan ini tidak berubah banyak sejak sensus 2000 . Tercatat perubahan kecil, tetapi perubahan ini dapat diabaikan. Lihat data BPS dalam Penduduk Indonesia Hasil SP 2010 (BPS, 2010).
} 
suara sebesar 26,6 persen dan 26,8 persen saja, yang jauh di bawah proporsi jumlah perempuan yang sebesar 50 persen, bahkan jumlah pemilih perempuan yang memberikan suara pada kandidat perempuan jauh lebih kecil lagi. Sementara itu, dalam pilkada serentak yang diselenggarakan tahun 2015, dari 123 calon kepala daerah atau wakil kepala daerah, terdapat 123 kandidat perempuan. Akan tetapi, hanya 35 calon yang terpilih atau hanya 28 persen saja dari jumlah keseluruhan calon (http://www. rappler.com/indonesia/115543-perempuanmenang-di-pilkada-2015). Alasan terpilihnya mereka bukan karena mereka mengusung isu-isu perempuan dalam kampanye, tetapi karena mereka adalah bagian dari dinasti politik atau yang kuat sumber dananya. Pada pilkada serentak 2017, jumlah calon kepala daerah atau wakil kepala daerah perempuan hanya mencapai proporsi 7 persen saja. (http://perludem.org/2016/11/30/keterlibatanperempuan-di-pilkada-menurun/).

Dengan demikian, meskipun secara etis, kampanye afirmasi terhadap kandidat perempuan dilakukan, kenyataan keras di lapangan tidak memberi bukti kokoh bahwa kandidat perempuan dan isu-isu perempuan dapat mendongkrak dukungan elektoral. Dari berbagai kriteria pengelompokan demografis, dalam kasus-kasus pilkada, tampaknya kriteria status suku, kedaerahan, agama, dan migran/transmigran jauh lebih memiliki nilai strategis secara elektoral - setidaknya di mata para elite politik nasional, terlebih lagi elite politik lokal. Berikut adalah penjelasannya satu per satu.

Suku. Populasi Indonesia tersusun dari banyak suku, tetapi komposisi sukunya tidaklah seimbang. Sensus Indonesia tahun 2010 mencatat 31 kategori suku atau etnis yang ada di Indonesia ${ }^{9}$ dan ini adalah pengelompokan yang besar saja. Di

\footnotetext{
9 "Kewarganegaraan, Bangsa, Agama, dan Bahasa Sehari-hari Penduduk Indonesia" (BPS, 2011). Dalam kerjanya mengoleksi data, para surveyor BPS sesungguhnya memegang kode 1.331 kategori suku, subsuku, dan sub-subsuku di Indonesia. Setelah
}

dalamnya, beberapa kelompok suku yang sebenarnya merupakan penggabungan dari beberapa suku dan subsuku. Papua, Maluku, dan Nusa Tenggara Timur (NTT), misalnya, merangkum semua kelompok suku atau subsuku di setiap wilayah tersebut.

Secara nasional, suku Jawa menyumbang sebesar sebesar 40,2 persen dari seluruh populasi Indonesia diikuti oleh suku Sunda 15,5 persen, Batak 3,8 persen, dan Madura 3 persen. Meskipun nama suku-suku lain cukup populer, sesungguhnya secara numerik jumlah mereka tidaklah besar karena berada di bawah ambang 3 persen. Suku-suku yang termasuk di sini adalah Minang, Melayu, Aceh, Bugis, dan Betawi. Di luar suku-suku ini, jumlah suku lain secara tersendiri jauh lebih sedikit lagi. Namun, jika semuanya dijumlahkan, berbagai suku selain yang telah disebutkan itu mencapai jumlah cukup besar, yaitu 27,1 persen dari total populasi.

Gambaran komposisi suku di tingkat nasional tidaklah paralel dengan komposisi di tingkat lokal. Di tingkat lokal, suku Jawa hanya dominan di dua provinsi: Jawa Tengah dan Jawa Timur. Di DKI Jakarta, suku Jawa tidaklah dominan, tetapi Jawa adalah suku yang jumlahnya paling besar, yakni 36,2 persen, dan jumlah itu melampaui suku Betawi yang berada di urutan kedua dengan proporsi 28,4 persen. Di provinsi-provinsi lainnya, suku Jawa adalah minoritas yang secara elektoral tidak penting.

Nilai strategis suku dan isu kesukuan dalam politik elektoral dapat muncul dalam tiga situasi. Pertama, hanya jika ketika komposisi kesukuan di sebuah unit atau wilayah elektoral bersifat heterogen. Kedua, secara numerik, ukuran populasi suku di luar suku mayoritas cukup besar. Ketiga, jika kompetisi pilkada berlangsung ketat, yakni ketika selisih suara dukungan antara

sensus baru, BPS melakukan pengelompokan lagi sehingga keluar profil suku yang jumlahnya lebih kecil. Sebenarnya masih terbuka bagi para peneliti untuk membuat pengelompokkan yang dimungkinkan oleh BPS. Lihat di https://www.bps.go.id/KegiatanLain/view/ id/127. 
pasangan kandidat yang bersaing tidak terlalu besar, terutama antara pasangan yang mendapat dukungan suara terbanyak dengan pesaing terdekatnya. Contoh penting yang disebutkan di sini adalah Provinsi Kalimantan Selatan (Kalsel) yang merupakan contoh kasus yang mendemonstrasikan bekerjanya faktor kesukuan pada pilkada 2010.

Populasi Kalsel relatif heterogen jika komposisi populasi dilihat dari segi suku yang berdiam di sana. Jumlah mayoritas tetap dipegang suku Banjar yang proporsinya mencapai 76 persen kemudian suku Jawa berada di urutan kedua dengan proporsi 13 persen dan Bugis 2,5 persen, sedangkan sisanya adalah berbagai suku lain yang kecil secara numerik. Kasus pilkada Kalsel memenuhi kriteria pertama yang telah disebutkan di atas. Ada derajat heterogenitas suku, yaitu proporsi Jawa cukup memiliki harga elektoral, begitu juga dengan Bugis meskipun dengan harga elektoral yang minimal. Namun, isu kesukuan tidak muncul pada lima bulan sebelum hari-H pemilihan.

Sembilan bulan sebelum pilkada berlangsung, calon atau pasangan inkumben jauh mengungguli dibandingkan dengan empat pasangan penantang. Gubernur inkumben adalah Rudy Arifin yang berpasangan dengan Rudy Resnawan. Sementara itu, penantangnya adalah Zairullah Azhar-Aboe Bakar Al-Habsyi, Rosehan NBSaiful Rasyid, Sjachrani Mataja-Gusti Farid Hasan Aman, serta Khairil Wahyuni-Alwi Syahlan. Sejak awal terlihat bahwa salah satu penantang adalah pasangan Zairullah-Aboe Bakar Al-Habsyi. Jarak jumlah dukungan dua pasangan ini pada Agustus 2009 atau delapan bulan menjelang hari-H pilkada lebih dari 30 persen. ${ }^{10}$ Pada survei Oktober 2009, jarak dukungan elektoral keduanya

10 Data survei ini diambil dari laporan lima rangkaian survei yang dijalankan oleh Lembaga Survei Indonesia sejak Agustus 2009 sampai dengan April 2010. Catatannya adalah pada survei Agustus 2009, penantang terkuat sesungguhnya adalah pasangan Rosehan NB dan Saiful Rasyid. Akan tetapi, pada surveisurvei setelahnya, pasangan ini semakin tertinggal dalam jajak pendapat di tingkat pemilih. menyempit dan tersisa 24 persen. Kompetisi di antara kedua pasangan ini semakin ketat sebagaimana terekam dalam survei Januari 2010 ketika jarak dukungan elektoral mereka tinggal satu digit, yaitu 7 persen. Rangkaian survei ini memberikan informasi bahwa tren dukungan pada pasangan Rudy Arifin-Rudy Resnawan terus menurun, sedangkan tren dukungan suara untuk pasangan ZairullahAboe Bakar Al-habsyi terus meningkat. Jika rerata kenaikan dukungan pasangan penantang setiap bulan adalah 9 persen, maka dalam rentang lima bulan menuju hari- $\mathrm{H}$ pilkada dapat diperkirakan bahwa pasangan penantang ini akan memenangi Pilkada Kalsel 2010. Informasi tentang penurunan dan kenaikan ini telah beredar di kalangan elite politik Kalsel saat itu. Dalam situasi seperti ini, opsi strategis apa saja yang tersedia bagi pasangan inkumben dalam upaya memenangi pemilu: mengangkat isu agama, isu etnis, atau isu migran dan migrasi dalam kampanye demi mendongkrak dukungan?

Opsi isu agama relatif sulit dimainkan oleh pasangan inkumben karena semua pasangan kandidat beragama sama, yakni Islam, agama yang dipeluk oleh mayoritas pemilih. Salah satu pasangan penantang, bahkan terlihat memiliki kredensial Islam yang lebih tebal. Zairullah berasal dari Bugis dan Aboe Bakar Al-Habsyi adalah keturunan Arab dengan afiliasi ke Parai Keadilan Sejahtera (PKS). Dengan latar belakang penantang seperti ini, pemanfaatan isu agama justru dapat menjadi bumerang secara elektoral bagi pasangan inkumben. Oleh karena itu, pilihan strategi elektoral Rudy Arifin dan Rudy Resnawan hanyalah memanfaatkan dua opsi sisanya, yakni isu etnis atau isu migran, atau kombinasi keduanya.

Memasuki Januari 2010, pasangan inkumben telah memilih opsinya. Rudy Arifin dan Rudy Resnawan adalah suku Banjar asli, sedangkan pasangan penantangnya jelas bukan asli Banjar. Zairullah adalah orang Bugis, sedangkan Aboe Bakar Al-Habsyi adalah keturunan Arab. Bagaimana pasangan 
inkumben memanfaatkan perbedaan suku ini? Kemudian mereka mengangkat isu etnis dan mulai menyebarkan slogan dalam kampanye bertema etnis: Asli Banua dan Asli Urang Banua, yang berarti asli suku Banjar.

Seberapa efektif mobilisasi elektoral berbasis etnis ini? Seorang surveyor dari Jaringan Suara Indonesia (JSI) dan Rizal Mallarangeng dari Fox Indonesia selaku konsultan politik mengatakan bahwa kampanye berisu etnis itulah yang menjadi modal pemulihan dukungan politik pemilih terhadap pasangan inkumben dan kunci pemenangan pilkada. ${ }^{11}$ AR Ansyari, Direktur Eksekutif Lembaga Kajian Pembangunan Banua (LKPB), secara retrospektif mengevaluasi, "Kita tahu dahulu Rudy Arifin bisa mengalahkan Zairullah Azhar karena mendorong isu asli Urang Banua (asli dari Kalsel). Zairullah Azhar yang asli Sulawesi bersama pasangannnya, Habib Aboebakar Alhabsyi dari Jakarta, kalah telak." (http:// politik.rmol.co/read/2015/07/19/210463/ Pengusaha-Tambang-Versus-UrangBanua-). Hasil pilkada gubernur tersebut diumumkan pada Juni 2010. Pasangan inkumben Rudy Arifin dan Rudy Resnawan mendapatkan 46,8 persen suara, sedangkan pasangan Zairullah dan Aboe Bakar AlHabsyi sebagai pesaing terdekatnya meraih 22,7 persen suara. Sisa suara terbagi untuk tiga pasangan lainnya.

Titik balik redistribusi dukungan suara terjadi menjelang Januari 2010 setelah pasangan inkumben memobilisasi isu etnis melalui slogan dan kampanye politik mereka. Melalui rekaman data survei, terlihat jelas bahwa sebelum Januari 2010 dukungan suara terhadap pasangan inkumben terus menurun, sedangkan dukungan suara pada

\footnotetext{
11 Lihat, http://www.antarakalsel.com/berita/88/asliurang-banua-dongkrak-suara. Surveyor dari Jaringan Suara Indonesia (JSI) dalam berita tersebut dikesankan sebagai surveyor yang merangkap sebagai konsultan politik salah satu pasangan calon. Sementara itu, pendapat dari Rizal Mallarangeng dinyatakannya dalam diskusi informal dengan penulis pada September 2010 ketika menceritakan pengalamannya sebagai konsultan politik pasangan penantang dalam pilkada tersebut.
}

pasangan penantang terus naik. Jarak elektoral yang lebar di antara kedua pasangan tersebut menyempit hanya 7 persen saat itu. Namun, setelah Januari dan setelah slogan Asli Banua merambah publik pemilih, jarak elektoral keduanya melebar lagi dan tren yang berkebalikan berlangsung sampai pada hari- $\mathrm{H}$ pilkada. Pendeknya, isu etnisitas ternyata berperan besar dalam kasus Pilkada Kalsel. Oleh karena itu, bukan hal yang mustahil jika di beberapa pilkada lain, isu etnis juga memiliki efek yang sama. Berikut ini adalah peran isu demografis lainnya dalam pilkada.

Putra Daerah. Ini adalah salah satu isu yang kerap muncul dalam gelanggang pilkada. Dalam derajat tertentu, istilah ini merujuk pada etnisitas. Namun, isu putra daerah masih dapat dibedakan dengan etnisitas ketika yang dibicarakan adalah penyelenggaraan sebuah pilkada di wilayah yang berkarakter multietnis: sebagian adalah suku asli dan sebagian lainnya adalah suku pendatang. Isu putra daerah dapat melampaui sekat kelompok etnis lokal yang asli dan mampu menyatukan etnis-etnis asli yang lokal. Akan tetapi, pada saat yang sama isu ini membelah populasi pemilih ke dalam kubu etnis-etnis lokal dan pendatang. Mobilisasi pemilih melalui isu putra daerah ini memuat kontroversi.

Secara formal, undang-undang tentang pemilu dan undang-undang tentang otonomi daerah tidak memberikan basis normatif yang memberikan keistimewaan bagi putra daerah untuk menjadi kepala daerah. Hal ini juga dinyatakan oleh mantan Ketua Pansus RUU Pemilu DPR RI, Ferry Mursyidan Baldan: "Tidak ada satu pun norma yang mengatur hanya putra daerah yang boleh mencalonkan diri sebagai kepala daerah." (http://www.antaranews.com/berita/177697/ isu-putra-daerah-dalam-pilkada-koyakkebangsaan). Di waktu yang sama, saat memberikan penjelasan itu pada wartawan, politikus Golkar yang kemudian berpindah ke Nasdem tersebut melanjutkan bahwa "[p] engaturan tentang norma yang kemudian diartikan keliru sebagai "Putra Daerah" 
sebenarnya dalam konteks affirmative policy'." (http://www.hukumonline.com/klinik/ detail/lt4f7b13d0c46aa/apakah-calon-kepaladaerah-harus-putra-asli-daerah-pemilihan-)

Konteks politik di sini adalah ketika undangundang sedang dirumuskan. Ketika undangundang tentang pemilu didiskusikan, tuntutan keadilan disuarakan dari berbagai daerah yang merasa kecilnya kesempatan politik mereka untuk menjadi kepala daerah. Sepanjang era Orde Baru banyak kepala daerah yang ditunjuk dari Jakarta dan calon yang ditunjuk umumnya bukan berasal dari daerah yang bersangkutan. Jika pun ada mekanisme pemilihan di level DPRD, sesungguhnya paket kepala daerah dan wakilnya telah lebih dulu ditentukan, sedangkan proses pemilihan di DPRD hanyalah bersifat seremonial belaka. Dalam konteks ini, sebagaimana dinyatakan oleh Ferry Mursyidan Baldan, isu putra daerah bermakna terbukanya kesempatan setara bagi putra daerah untuk menjadi kepala daerah. Dengan kata lain, basis penentuannya bukan berdasarkan pada loyalitas politik atau asal/suku daerah, tetapi atas dasar kualitas dan prestasi sama atau lebih baik. Dengan penyetaraan peluang politik itu, para putra daerah memiliki kesempatan yang sama dengan kandidat yang nonputra daerah.

Namun, di lapangan konteks normatif tersebut tidak otomatis berjalan serta menjadi pedoman perilaku elite dan pemilih di gelanggang pilkada. Oleh karena itu, isu putra daerah di pemilu lokal dapat memiliki empat kemungkinan berikut. (1) Isu putra daerah dianggap penting oleh elite politik lokal dan publik pemilih. (2) Isu ini dianggap penting oleh elite, tetapi tidak dianggap penting oleh pemilih. (3) Sebaliknya, elite tidak menganggapnya penting, sedangkan publik menganggapnya penting. (4) Keduanya, baik elite maupun publik, tidak menganggap isu putra daerah sebagai isu penting dalam pilkada.
Dengan sekitar 538 pilkada di seluruh Indonesia yang mencakup pilkada provinsi, kabupaten, dan kota, kemunculan isu putra daerah pastilah akan bervariasi. Di provinsi baru Kalimantan Utara (Kaltara), misalnya, sekitar separuh pemilih mengatakan bahwa mereka menginginkan putra daerah yang menjadi gubernur. ${ }^{12}$ Dengan kata lain, satu dari dua pemilih Kaltara menganggap bahwa isu putra daerah adalah isu penting. Sementara itu, dalam derajat yang lebih rendah, di Kabupaten Malinau dan Bontang, isu putra daerah juga menjadi alasan sebagian pemilih memberikan suaranya kepada kandidat yang asli warga di wilayah tersebut. ${ }^{13}$

Di Lampung, isu putra daerah jelas dianggap penting, setidaknya di tingkat elite. Pakem politik yang berkembang di sana adalah pakem memasangkan calon dengan latar belakang pendatang dengan putra daerah. ${ }^{14}$ Demografi etnis di Lampung yang berpenduduk 7,6 juta jiwa terdiri atas tiga suku besar: Jawa 61 persen, penduduk asli 25 persen, dan Sunda 11 persen. Sisanya terbagi dalam berbagai suku lainnya. Dalam percakapan populer, dominasi Jawa membuat Lampung sering dijuluki sebagai "Jawa Utara”. Komposisi seperti itu pada gilirannya membangkitkan sentimen kedaerahan di kalangan warga asli.

Sentimen kedaerahan mulai merebak di kalangan warga Lampung sejak era otonomi daerah, yaitu ketika sejumlah tokoh asli daerah, seperti Sjachrudin ZP dan Dianis Thabrani, mulai tampil dalam gelanggang

12 Survei Indikator Politik Indonesia, Mei 2015 untuk Provinsi Kaltara. 13 Survei Indikator Politik Indonesia, Mei 2015 untuk
Kabupaten Malinau dan Bontang.

14 Pemilu kepala daerah (pilkada) 30 Juni 2010 yang berlangsung serentak di lima kabupaten/kota di Lampung banyak memakai pakem kombinasi Jawa-Lampung. Ini terjadi di Bandarlampung, Lampung Timur, Metro, Lampung Selatan, dan Pesawaran. Lihat di http://bisniskeuangan.kompas. com/read/2010/10/29/03123960/putra.daerah.dan. aristokrasi.politik 
politik lokal Lampung. Sjachroedin ZP yang menjabat sebagai Gubernur Lampung tahun 2004-2008 membuat sejumlah langkah "pribumisasi". Nama bangunan dan ruangruang kantor dinas yang semula bernuansa Jawa diubah dan diganti menjadi nama-nama Lampung. Pendapa gubernuran, misalnya, sejak saat itu disebut dengan mahan agung (http://bisniskeuangan.kompas.com/ $\mathrm{read} / 2010 / 10 / 29 / 03123960 /$ putra.daerah. dan.aristokrasi.politik). Saat itu gubernur belum dipilih langsung, tetapi dipilih melalui DPRD dan saat itu citra Sjachroedin yang mantan perwira polisi telah dikenal sebagai seorang putra daerah. ${ }^{15}$ Dengan demikian, terpilihnya Sjachroedin ZP tahun 2004 hanya dapat membuka perilaku elite DPRD, bukan perilaku pemilih. Baru pada 2009 putra daerah ini terpilih kembali melalui pemilihan langsung gubernur. Pertanyaannya adalah sejauh mana isu putra daerah ini penting bagi pemilih Lampung?

Beberapa ilustrasi kualitatif memberikan informasi bahwa isu putra daerah ini penting bagi warga asli Lampung. Pertama, kalau pasangan kombinasi sebagai pakem politik lokal di Lampung itu dapat dijadikan indikasi, dalam derajat tertentu dapat ditafsirkan bahwa pembelahan dan penonjolan isu putra daerah memiliki resonansi di tingkat pemilih, baik di tingkat provinsi maupun tingkat kabupaten/ kota, pada pemilu serentak di enam kabupaten/kota tahun 2010. Kedua, isu putra daerah ini masih bertahan sampai sekarang ketika gelombang pemilu serentak tahun 2017 juga akan berlangsung di kabupaten/kota di wilayah Provinsi Lampung. Partai politik pengusung kandidat, selain memperhitungkan peluang kandidat yang diajukannya, mereka juga menimbang atribut putra daerah sebagai kriteria pemberian dukungan atau

15 Ketika bursa menteri sedang ramai di media setelah Joko Widodo dan Jusuf Kalla memenangi Pemilu Presiden 2014, bahkan Sjachroedin disorongkan Seknas Jokowi-JK Lampung sebagai salah seorang calon menteri dengan emblem putra daerah. Lihat, http://bisniskeuangan.kompas.com/ $\mathrm{read} / 2010 / 10 / 29 / 03123960 /$ putra.daerah.dan. aristokrasi.politik pencalonan diri seperti yang terjadi di Kabupaten Pringsewu (http://harianlampung. com/index.php?k=politik\&i=20151-golkarusung-tiga-petahana-pada-pilkada-2017). Hal yang sama juga terjadi untuk calon-calon di Kabupaten Tubabar (https://www.harianfokus. com/2016/05/08/pkb-target-wakil-di-pilkadatubabar/), Lampung Barat (http://www. haluanlampung.com/index.php/politik/10507parosil-mabsus-serahkan-berkas), Lambar (http://www.jpnn.com/news/kakak-andi-ariefsiap-maju), dan kabupaten/kota lainnya.

Sejumlah ilustrasi ini tidak secara langsung memberikan bukti dan gambaran perilaku pemilih. Namun, dapat ditafsirkan bahwa penonjolan atribut putra daerah oleh elite politik mengimplikasikan sebagian pemilih juga menganggap faktor kedaerahan tersebut sebagai hal penting. Yang pasti, di tingkat elite lokal, isu kedaerahan atau putra daerah menjadi faktor penting dalam berstrategi mencari kombinasi pasangan kepala daerah dan wakil kepala daerah yang cocok, yaitu salah satunya haruslah putra daerah.

Agama. Selain isu etnis dan kedaerahan, isu agama adalah isu demografis yang juga sering menjadi faktor penting dalam berbagai pilkada. Akan tetapi, komposisi demografi penduduk Indonesia berdasarkan pemelukan agama ini perlu dicermati dengan seksama.

Proporsi pemelukagamalslam di Indonesia, menurut Sensus BPS 2010, mencapai 87,3 persen, sedangkan gabungan antara pemeluk agama Kristen Protestan dan Katolik sebesar 9,8 persen. Selebihnya, gabungan pemeluk agama Budha, Hindu, dan Konfusianisme hanya sebesar 3 persen. Dengan melihat komposisi populasi yang bermayoritas Islam tersebut, isu agama mestinya bukanlah isu penting secara elektoral setidaknya di tingkat nasional. Karena pemilu adalah soal jumlah, maka jumlah pemeluk agama terbesar akan selalu memenangkan pemilu. Namun, telah menjadi pengetahuan umum bahwa kenyataan di lapangan jauh lebih kompleks. 
Clifford Geertz (1976) adalah seorang antropologis yang sejak awal melihat nuansa perbedaan di antara pemeluk agama Islam di sebuah kota kecil di Jawa Timur: Mojokuto (Pare). Secara formal, mereka adalah muslim, tetapi Geertz membedakan mereka menjadi yang menjalankan rukun Islam (santri) dan yang tidak menjalankannya (abangan atau priayi). Sejumlah ahli politik kemudian memakai kategorisasi kelompok keagamaan ini untuk memprediksi perilaku dan preferensi politik para muslim ini. ${ }^{16}$

Untuk masa sekarang, kategorisasi muslim sebagaimana dilakukan Geerzt perlu dimodifikasi. Basis idenya sama bahwa muslim bukanlah sebuah kelompok homogen, tetapi ekspresi dan implikasinya terhadap preferensi politik mereka yang perlu dimodifikasi. Isu-isu tentang Islam transnasional, terorisme, dan pendidikan terpadu belum muncul saat Geertz mempublikasikan hasil studinya. Namun, kini isu-isu itu membelah muslim dalam sejumlah kubu. Demikian juga ekspresi-ekspresi politik dan preferensi politik mereka.

Sejumlah media merekam yang disebut sebagai conservative turn atau titik belok konservatisme di kalangan Muslim di Indonesia. ${ }^{17}$ Konservatisme ini mengambil bentuk yang bervariasi mulai dari yang lunak sampai dengan ekspresi yang memuat kekerasan. Contoh konservatisme lunak adalah ekspresi perubahan cara berpakaian yang ditandai dengan merebaknya pemakaian jilbab dan baju koko, pendirian sekolah-sekolah Islam terpadu, serta ramainya pengajian

16 Lihat, antara lain, Afan Gaffar (1992), Javanese Voters: A Study of Election Under a Hegemonic Party System, Yogyakarta: Gadjah Mada University Press dan Dwight King (2003), Half-hearted Reform: Electoral Institutions and the Struggle for Democracy in Indonesia. Westport, CT: Praeger.

17 Lihat, misalnya, di Rappler http://www.rappler.com/ world/regions/asia-pacific/indonesia/english/155485conservatives-muslims-ahok-opinion atau The Wall Street Journal http://www.wsj.com/articles/hard-linestrain-of-islam-gains-ground-in-worlds-largest-muslimcountry-1478248172 dan The Jakarta Post, http:// www.thejakartapost.com/news/2015/11/05/risingconservatism-asia.html. dan majelis-majelis taklim di kalangan kelas menengah. ${ }^{18}$ Sementara itu, konservatisme yang memuat kekerasan adalah, seperti ekspresi dalam bentuk penyegelan gereja, pembubaran diskusi-diskusi yang bertema kiri, bahkan sampai pada peledakan bom terorisme. Di banyak provinsi atau kabupaten/ kota, syariah diadopsi menjadi peraturan daerah sebagai basis kebijakan dan tindakan aparat pemerintahan lokal. Pertanyaannya adalah sejauh mana perubahan di tingkat individu dan sosial ini diterjemahan di wilayah politik? Dirumuskan secara berbeda, sejauh mana isu dan tren konservatisme ini dimobilisasi oleh para elite lokal dalam pilkada dan sejauh mana pula konservatisme ini membentuk pilihan politik pemilih?

Pengadopsian perda syariah adalah sebuah cerminan konservatisme dalam keberagamaan meskipun konservatisme agama tidak secara otomatis akan diterjemahkan ke dunia politik. Dapat saja terjadi, konservatisme dalam arti kesalehan meningkat memang membentuk pilihan politik. Namun, dapat juga terjadi bahwa konservatisme itu hanya terekspresikan di ruang pribadi atau sosial, tidak membentuk pilihan politik. Dengan kata lain, sikap individual dan sikap sosial pemilih berkarakter konservatif, tetapi sikap politiknya tetap sekuler. Contoh menarik yang dapat ditampilkan di sini adalah kasus Pilkada Jakarta 2012.

Pada putaran pertama, semua isu muncul secara serentak, mulai dari isu kebijakan dan kinerja inkumben dalam menangani berbagai permasalahan sosial ekonomi Jakarta, isu etnis, dan agama. Isu agama berkembang menjadi isu prominen di putaran kedua yang mempertandingkan dua pasangan teratas: Foke-Nara (Fauzi Bowo dan Nachrowi Ramli) dan Jokowi-Ahok (Joko Widodo dan Basuki Tjahaja Purnama).

\footnotetext{
18 Sebuahgambaran riil dilapanganyang mencerminkan meningkatnya konservatisme di kalangan elite dapat dibaca pada artikel penelitian yang ditulis oleh Colm Fox dan Jeremy Menchik, yang dipresentasikan pada pertemuan tahunan APSA 2011.
} 
Dalam kampanye, sejumlah selebritas dan tokoh masyarakat mengangkat isu agama untuk membantu peningkatan elektabilitas pasangan Foke-Nara. Rhoma Irama, misalnya, menyuarakan potongan ayat kitab suci yang melarang pemilih memilih pemimpin kafir pada awal Agustus 2012 (http://fokus.news. viva.co.id/news/read/343144-pertarunganpilkada-dki-putaran-ii-memanas). Jelas kampanye ini dialamatkan ke pasangan Jokowi-Ahok karena Ahok bukanlah seorang muslim. Seruan yang sama dilakukan oleh Habib Abdurrahman Al Habsyi untuk jemaat majelis taklim di Islamic Center Kwitang, Jakarta Pusat pada 13 Agustus 2012 (http:// www.beritasatu.com/megapolitan/65942lagi-isu-sara-diangkat-supaya-dukung-foke. html). Yang menjadi masalahnya adalah kedua tokoh ini, menurut Tim Advokasi FokeNara, bukanlah bagian dari tim kampanye resmi pasangan tersebut (http://fokus.news. viva.co.id/news/read/343144-pertarunganpilkada-dki-putaran-ii-memanas). Namun, dalam kampanye putaran kedua di Kuningan Barat, Fauzi Bowo juga memanfaatkan isu agama untuk memobilisasi pemilih agar mendongkrak suara di putara kedua pilkada (http://www.antaranews.com/berita/333023/ foke-kampanye-di-kuningan-barat). Sampai di sini jelas bahwa isu agama diaktivasi oleh elite pada Pilkada Jakarta 2012. Sejauh mana aktivasi isu agama ini membawa efek pada pilihan politik pemilih di Jakarta?

Dari analisis data survei yang dikerjakan oleh Lembaga Survei Indonesia (bekerja sama dengan majalah Tempo), efek kampanye berbasis agama terhadap pilihan politik pemilih adalah signifikan. ${ }^{19}$ Dalam dunia sosial riil yang jauh lebih kompleks, efek agama atas pilihan politik pemilih tentunya tidak bekerja sendirian sebagai faktor tunggal untuk memformat pilihan

\footnotetext{
19 Faktor lain yang diukur dan dimasukkan dalam analisis multivariat LSI adalah kinerja petahana, persepsi pemilih terhadap kondisi ekonomi, etnisitas, tingkat pendidikan, tingkat penghasilan, jenis kelamin dan usia (Laporan Survei DKI Jakarta, LSI-Tempo, September 2012).
}

politik pemilih. Bersama dengan faktor-faktor lainnya, agama membentuk preferensi politik pemilih. Pertanyaan yang secara teknis dan strategis lebih relevan adalah seberapa besar kontribusi faktor itu menentukan proses pemberian suara pemilih kepada para kandidat di pilkada dan seberapa besar variasi yang dapat dijelaskan oleh sebuah model statistik regresi ketika variabel agama dimasukkan di dalamnya.

Akan tetapi, di luar isu teknis uji statistik, secara intuitif dapat diidentifikasikan peran faktor dan isu agama dalam Pilkada Jakarta. Sampai hari ini pun, bahkan dalam Pilkada Jakarta tahun 2017, isu yang sama muncul lagi dengan desakan yang jauh lebih kuat. Tuduhan bahwa Basuki Tjahaja Purnama, sang petahana yang berlaga kembali pada Pilkada Jakarta kali ini, melakukan penistaan agama dalam kunjungan dan pertemuannya dengan warga Kepulauan Seribu telah menyulut demonstrasi besar-besaran di Jakarta pada 4 November dan 2 Desember 2016. Efek faktor dan isu agama ini direkam dengan baik dalam survei opini publik yang dilakukan oleh Lembaga Survei Indonesia sepanjang tahun 2016 . Jika pada paruh awal 2016 dukungan publik terhadap petahana sangat tinggi karena alasan kinerjanya yang bagus, dukungan itu secara drastis melorot pada akhir tahun. Salah satu alasan yang disebut pemilih dalam memberikan suaranya adalah alasan agama. ${ }^{20}$

Sampai di sini kasus Pilkada Jakarta membuktikan bahwa faktor agama adalah faktor penting dalam pilkada. Letak penting faktor ini berada di dua level, yakni level elite dan level pemilih. Elite dapat memilih untuk mengaktivasi isu-sisu agama dalam pilkada atau membiarkannya dormant atau terpendam. Demikian juga pemilih dapat merespons aktivasi tersebut dengan dua cara, yaitu merespons aktivasi isu agama sebagai dasar untuk memilih atau membiarkan saja proses aktivasi itu dan memilih secara

20 Rilis survei LSI "Likeability is Electability?" Laporan Survei 3-11 Desember 2016. 
mandiri. Variasi kemungkinan ini dapat terjadi di berbagai pilkada.

Transmigrasi dan transmigran. Ini adalah pengelompokan demografis lain lagi yang dapat menjadi faktor penting dalam pilkada. Faktor ini dengan sendirinya hanya akan muncul dan berdampak di wilayah-wilayah yang terdapat transmigran dalam jumlah yang cukup signifikan. Di wilayah-wilayah yang tidak terkena atau tidak menjadi daerah tujuan transmigrasi, isu ini sama sekali tidak relevan dalam pembicaraan tentang strategi elektoral di pilkada.

Data tentang program transmigrasi yang dikeluarkan tahun 2015 oleh BPS yang memberikan sedikit gambaran tentang persebarannya. Pada 2013 dari 25 provinsi yang menjadi tujuan transmigrasi, hanya 7 provinsi yang tidak menjadi daerah penempatan, yakni Sumatera Utara, Sumatera Barat, Riau, Jambi, Lampung, Bangka-Belitung, dan Kalimantan Selatan. Dalam hitungan jumlah kartu keluarga (KK), Provinsi Sulawesi Utara dan Maluku Utara menerima jumlah yang paling sedikit, yakni 10 KK. Sementara itu, penerima transmigran paling banyak adalah Kalimantan Utara (449 $\mathrm{KK})$.

Untuk jumlah transmigran yang terbesar pun, angka itu tidak penting secara elektoral, tetapi angka itu hanyalah untuk satu tahun. Kenyataannya, program transmigrasi telah berlangsung sejak zaman kolonial dan berlanjut sampai sekarang. Sebagaimana contoh Provinsi Lampung, sekitar 60 persen warga Lampung adalah warga keturunan Jawa yang merupakan sumber transmigran terbesar. Dari 60 persen ini, sebagian besar mereka adalah para transmigran yang didatangkan melalui program pemerintah. Jumlah transmigran yang besar ini pasti memiliki efek pada politik pilkada. Variasi jumlah transmigran ini memerlukan pengolahan tersendiri sebelum peran transmigran dalam politik pilkada dilihat. Akan tetapi, artikel ini membatasi diri hanya pada sejumlah kasus pilkada yang di dalamnya kelompok transmigran dan isu-isu yang berkaitan dengan kepentingan transmigran menjadi isu penting dalam pilkada.

Sebuah pernyataan yang dikeluarkan tahun 2012 oleh Menteri Tenaga Kerja dan Transmigrasi saat itu, Muhaimin Iskandar, berisi imbauan agar para kandidat yang bertarung dalam pilkada tidak membawa isu transmigrasi dan transmigran dalam kampanye mereka (http://www.republika. co.id/berita/nasional/politik/12/11/26/me3hcnpolitik-pilkada-jangan-dibawa-ke-kawasantransmigrasi). Pernyataan ini merefleksikan besaran transmigrasi (dari segi jumlah dan keluasan cakupan wilayah), sebab sang menteri memerlukan diri untuk membuat sebuah pernyataan. Namun, sebagaimana terjadi pada isu kesukuan dan agama, para kandidat yang bertarung di gelanggang pilkada memiliki pertimbangan sendiri. Sejauh perhitungan mereka, isu transmigrasi dapat memberikan tambahan dukungan elektoral, bahkan mungkin menentukan sehingga peran transmigran dan isu transmigrasi ini menyelinap dalam beberapa format.

Di Kabupaten Rokan Hulu, Riau, para transmigran memiliki organisasi PATRI (Perhimpunan Anak Transmigran Republik Indonesia) yang cukup aktif. Tahun 2015 organisasi ini sempat akan mencalonkan ketua organisasinya untuk maju dalam kandidasi bupati di sana. Berdasarkan perkiraan mereka, proporsi warga transmigran di Rokan Hulu mencapai 67 persen. Namun, sang ketua batal mencalonkan diri dan memilih untuk menyalurkan kepentingan kolektif para transmigran kepada kandidat bupati yang akan berlaga (http://riaumandiri.co/mobile/ detailberita/15858/warga-eks-transmigrasidiperhatikan.html). Model pencalonan diri atau kanalisisasi kepentingan kelompok transmigran melalui kandidat lain di pilkadapilkada juga terjadi di daerah-daerah lainnya. Warga Sentani di Kabupaten Jayapura, Papua, juga menggunakan kedua cara ini. Bupati petahana, Mathius Awaitouw, mengambil 
pasangan yang berlatar belakang transmigran, Giri Wijayantoro. Sementara itu, sejumlah warga transmigran di Distrik Namblong dan Distrik Nimbokrang (dua distrik di Kabupaten Jayapura) menyampaikan keluhan secara publik tentang kesulitan mereka menggarap lahan pertanian karena tanah mereka diblok warga asli yang mengklaim tanah garapan transmigran sebagai tanah ulayat (http://news. okezone.com/read/2016/10/25/340/1523611/ transmigran-minta-paslon-peserta-pilkadakabupaten-jayapura-tak-umbar-janji). Oleh karena itu, mereka ingin para kandidat bupati yang berlaga di Pilkada Kabupaten Jayapura tidak hanya mengumbar janji, tetapi menangani persoalan warga transmigran dengan kebijakan. Pendeknya, isu-isu identitas dan kebijakan yang menyangkut kepentingan transmigran kerap muncul di berbagai pilkada.

Dengan melihat sejumlah kasus ilustratif ini, maka pembelahan demografis antara warga pendatang (transmigrasi dan/atau migran) dengan warga asli adalah isu politik yang dapat menentukan hasil sebuah pilkada. Selanjutnya akan dilihat hubungan antara pembelahan dan pengelompokan demografis ini dengan pilihan politik pemilih pada bagian berikut ini.

\section{Kampanye dan Target Demografi}

Pembelahan dan pengelompokan demografis dalam pilkada - dan pemilu pada umumnya - memiliki dua tujuan. Pertama adalah efisiensi dalam manajemen pemenangan pilkada. Tanpa pemetaan politik dan penentuan target pemilih yang diprioritaskan, kegiatan kampanye hanya akan berujung pada pemborosan sumber daya sang kandidat, mulai dari sumber daya keuangan, waktu, dan personel. Semakin besar ukuran populasi akan semakin luas sebaran populasi. Semakin heterogen populasinya akan semakin penting dan mendesak pula kebutuhan pemetaan politik dan menentukan target pemilih, bahkan untuk calon yang memiliki sumber daya finansial besar. Kedua, arti penting pemetaan politik berkaitan dengan isi dan format pesan kampanye yang hendak disampaikan ke publik pemilih. Percuma belaka jika tim kampanye merancang dan membuat sebuah pesan kampanye tanpa mengetahui target pemilihnya. Pendeknya, pemetaan dan pengelompokan demografis bersifat wajib dalam setiap perumusan strategi pemenangan elektoral bagi kandidat di pilkada. Sebelumnya akan dilihat tautan antara faktor-faktor demografis dengan pilihan politik.

Kampanye adalah dasar yang menghubungkan faktor demografis dengan pilihan politik. Akan tetapi, model tautan melalui kampanye ini terbagi dalam dua jenis: tautan programatik atau tautan substantif yang berbasis isu kebijakan dan tautan primordial atau simbolis yang berbasis kesamaan atribut demografis. Kasus terakhir yang menyajikan pembelahan dan pengelompokan yang membagi warga transmigran (pendatang) dengan warga asli dapat adalah contoh tautan kedua yang berbasis pada kesamaan atribut demografis yang bersifat primordia. Ketika warga transmigran memilih calon gubernur atau bupati/wali kota karena melihat kesamaan atribut sebagai sesama transmigran (seperti kasus di kabupaten di Jayapura) sebagai titik tolak menentukan pilihan kandidatnya, yang berkembang atau dikembangkan adalah tautan simbolis. Baik pemilih maupun kandidat, keduanya tidak membicarakan program. Pemilih tidak mengajukan tuntutan agar kepentingan kolektifnya dapat dipenuhi melalui kebijakan, sedangkan kandidat tidak menawarkan kebijakan apapun untuk menjawab tuntutan tersebut. Hal ini dapat terjadi dan berlaku untuk pengelompokan demografis lainnya.

Slogan "jangan memilih calon kepala daerah pemimpin kafir", misalnya, tidak menuntut kandidat untuk membuat program dan merumuskan sebuah kebijakan publik. Slogan ini mengimplikasikan kepada pemilih 
bahwa alasan kesamaan agama antara kandidat dan pemilih adalah alasan yang cukup bagi pemilih untuk memberikan suara mereka tanpa perlu sang kandidat merumuskan sebuah program kebijakan. Secara visual, untuk memperoleh dukungan politik dengan cara ini, kandidat caleg dan kepala daerah tampil dalam fotonya dengan baju religius atau baju daerah. Jika kandidatnya lakilaki, maka ia memakai peci atau sorban dan memakai baju koko; sedangan kandidat perempuan memakai penutup kepala longgar atau jilbab. Dengan penampilan seperti itu, pesan yang mereka sampaikan melalui media kampanyenya adalah pesan simbolis bahwa pemilih yang seagama akan memilih kandidat yang seagama (atau sesama orang saleh) dan pemilih yang memiliki latar belakang etnis memilih kandidat yang berlatar belakang etnis yang sama. Kesamaan identitas agama dan etnisitas ini justru jauh lebih kuat ketimbang kesamaan status transmigran.

Tautan programatik lebih bersifat substantif karena hubungan antara pemilih dengan kandidat dibangun melalui program dan isu kebijakan publik. Kelompok pemilih yang memiliki kesamaan karakteristik demografis mengajukan tuntutan agar permasalahan yang mereka hadapi dijawab dengan sebuah tawaran kebijakan oleh (para)kandidat. Secara bersama, para anggota kelompok demografis ini memiliki kepentingan kolektif yang sama. Dalam kasus empiris, para transmigran di Kabupaten Jayapura yang dikutip di bagian sebelumnya memiliki kepentingan kolektif berupa hak pemilikan tanah garapan dan keleluasaan untuk membudidayakannya. Klaim para transmigran ini bertabrakan dengan klaim tanah ulayat yang diajukan penduduk lokal. Para kandidat yang sedang berlaga di pilkada diminta untuk memberikan opsi penyelesaian sebagai janji yang kelak akan dipenuhinya jika memenangkan pilkada. Pada kasus lain, kepentingan kolektif para transmigran berbentuk tuntutan agar anak-anak mereka diberi peluang untuk menjadi pegawai - kontrak atau PNS - di kawasan pemekaran di Kabupaten
Kuansing, Riau (http://www.riauterkini.com/ politik. php?arr $=99404$ \&judul=Pilkada $\% 20$ Kuansing, \% 20 Warga $\% 20$ ek s \% 20 Transmigran $\% 20$ Yaman $\% 20$ dengan $\% 20$ Kepemimpinan\%20MH).

Dari sisi transmigran sebagai kelompok kolektif dan sebagai pemilik hak suara dalam pilkada, mereka dapat mengembangkan tautan simbolis maupun maupun tautan substantif dengan para kandidat. Pada sisi lainnya, kandidat dapat pula memilih melakukan aktivasi isu identitas transmigran sehingga ia mengembangkan tautan simbolis. Namun, dapat juga sang kandidat memilih mengaktivasi isu-isu kepentingan kolektif dari kelompok pemilih transmigran dengan menawarkan kebijakan yang yang bersifat substantif.

Kemungkinan-kemungkinan yang sama juga berlaku untuk kelompok-kelompok demografis yang berbasis agama, etnisitas, dan kedaerahan. Kedua belah pihak dapat memilih mengembangkan tautan simbolis atau memilih mengembangkan tautan substantif.

Berbagai kebijakan afirmatif di tingkat lokal yang berbasis pengelompokan demografis yang dipraktikkan di daerah-daerah dapat dijadikan contoh kasus. Kebijakan afirmatif adalah kebijakan pemerintah (daerah) yang bersifat emansipatoris dengan tujuan untuk memajukan kehidupan ekonomi atau politik kelompok demografis tertentu. Misalnya, kebijakan yang diberi slogan Bela-beli Kulon Progo, Yogyakarta, bertujuan untuk memajukan kehidupan ekonomi warga Kulon Progo saja dengan menganjurkan penduduk di sana membeli produk-produk Kulonprogo sendiri - terutama produk pertanian (http:// news.detik.com/berita/3102031/bela-belikulonprogo-spirit-dan-sukses-bupati-hastoangkat-produk-lokal). Sekadar perbandingan, prinsip kebijakan ini mirip dengan, misalnya, kebijakan afirmatif di sektor pendidikan di Amerika Serikat yang ditujukan pada sukusuku minoritas yang secara sosial ekonomi tertinggal dibandingkan dengan kelompok- 
kelompok etnis lainnya (Anderson, 2005). Kebijakan afirmatif juga lazim juga terjadi pada daerah-daerah yang perkembangan sosial ekonominya dibandingkan dengan daerah lainnya. Contoh lain lagi adalah perkreditan syariah mungkin dapat juga dijadikan contoh eksperimen untuk sebuah kebijakan afirmatif yang dapat ditawarkan untuk mengembangkan tautan substantif pada kelompok muslim.

Dalam banyak kasus pilkada, contohcontoh empiris yang muncul sebagaimana dikutip pada bagian sebelumnya lebih menunjukkan maraknya kampanye yang bersifat simbolis ketimbang substantif. Namun, pada titik ini tidak dapat digambarkan seberapa ekstensif mode kampanye simbolis ini terjadi di berbagai pilkada, sebab ini memerlukan penelitian dan data tersendiri.

\section{Epilog}

Artikel ini telah memberikan gambaran empiris tentang bekerjanya faktor-faktor demografis dalam pilkada dan penilaian normatif yang berkaitan dengan penggunaan isu-isu simbolis. Penekanan pada isu-isu simbolis ini pada gilirannya membangkitkan sentimen primordial dalam kampanye pilkada serta efeknya terhadap kualitas praktik demokrasi di tingkat lokal. Bagian ini mendiskusikan implikasi teoretis dan normatif dari berbagai kasus yang disampaikan di atas.

Gambaran empiris itu mendedahkan informasi tentang cara para elite lokal - atau lebih spesifik lagi para kandidat di pilkada - memanfaatkan pemetaan politik yang bertumpu pada pengklasifikasian pemilih ke dalam kelompok-kelompok demografis dan pengidentifikasian kecenderungan preferensi politik yang muncul pada tiap-tiap kelompok sosial. Secara intuitif, para kandidat tersebut meyakini bahwa kesamaan atribut sosial yang dimiliki para pemilih membentuk pilihan politik mereka. Pengetahuan intuitif tersebut berkembang dan mendapatkan penguatan dalam praktik kampanye dengan hadirnya lembaga-lembaga survei dan bisnis-bisnis konsultasi politik yang menjangkau seluruh wilayah Indonesia. Dalam praktiknya, strategi elektoral para kandidat menyasar kelompokkelompok sosial yang diprioritaskan dan memobilisasi mereka melalui pembangkitan sentimen primordial dan/atau pembangkitan rasionalitas mereka. Dari serangkaian faktorfaktor demografis yang dianggap berpengaruh, para kandidat lebih mengutamakan sejumlah faktor demografi ketimbang yang lainnya. Faktor demografis agama, suku, dan kedaerahan lebih sering dieksploitasi para kandidat dalam kampanye pilkada ketimbang faktor jenis kelamin, usia, dan kelas sosial.

Sesungguhnya, ini adalah praktik lazim, baik di negara-negara demokrasi maju maupun negara-negara demokrasi baru. ${ }^{21}$ Dalam literatur tentang perilaku pemilih, efek faktor-faktor demografis yang dipercaya membentuk preferensi politik pemilih dikenal dalam model sosiologis perilaku pemilih, yakni model penjelasan perilaku pemilih yang paling awal muncul dalam studi di wilayah ini (Dalton, 2013). Pertanyaan empirisnya adalah sejauh mana model ini ditopang bukti empiris serta faktor-faktor demografis itu berpengaruh dan membentuk pilihan politik para pemilih? Tanpa topangan pembuktian empiris, efek faktor demografis terhadap preferensi politik hanyalah sekadar mitos.

Pada kenyataannya, dunia nyata panggung politik pilkada tidak memberikan kemewahan dan keleluasaan untuk semua proses pengujian secara akademis yang lebih rinci dan lebih dapat dipertanggungjawabkan, baik karena alasan ketersediaan waktu maupun karena alasan kepraktisan belaka. Hal ini karena klien-klien politik calon kepala daerah jarang memiliki pengetahuan dan menguasai teknik uji statistik regresi, misalnya. Oleh

21 Misalnya, Russell Dalton (2013), Citizen Politics: Public Opinion and Political Parties in Advanced Industrial Democracies. Los Angeles: CQ Press (atau edisi-edisi sebelumnya). 
karena itu, laporan-laporan standar dalam survei-survei pilkada dan rekomendasi yang diberikan pada klien umumnya sebatas menampilkan tabulasi silang antara berbagai variabel demografi dengan preferensi politik pemilih. Di sana tidak terpampang analisis bivariat dan analisis multivariat yang dapat memberikan informasi yang lebih meyakinkan bahwa efek faktor demografi terhadap pilihan politik pemilih di pilkada adalah riil atau spurious - efek sebuah variabel menghilang ketika variabel lain dimasukkan dalam model.

Sejauh ini sebuah studi sistematis yang pernah dilakukan oleh Saiful Mujani, R. William Liddle, dan Kuskridho Ambardi serta dipublikasikan empat tahun lalu dapat dijadikan sebagai perbandingan atau pijakan (Mujani, Liddle, Ambardi, 2012). Studi yang didasarkan pada data survei nasional ini menguji sejumlah model perilaku pemilih yang salah satu di antaranya adalah pengujian model sosiologis.

Melalui analisis bivariat, mereka menemukan bahwa faktor suku memiliki pengaruh signifikan pada perilaku pemilih di pemilu legislatif dan pemilu presiden. Akan tetapi, ketika faktor suku ini dikontrol oleh faktor demografis lain, faktor psikologis (kualitas tokoh dan identitas kepartaian), dan faktor ekonomi politik, maka efek suku melemah dan menghilang. Dengan kata lain, faktor demografis tersebut ternyata hanya bersifat spurious atau tidak nyata.

Sebagai sebuah isu akademis, tentulah kesimpulan ini bukanlah hasil final. la harus terus-menerus diuji dan model perilaku pemilih masih membuka sebuah ruang untuk perbaikan. Namun, sebuah catatan penting harus segera dikemukakan di sini: model dan data yang disajikan dalam studi itu adalah model perilaku pemilih pada pemilu level nasional. Untuk satu kemungkinan, kesimpulan itu dapat berlaku juga di tingkat lokal - dalam berbagai pilkada. Untuk kemungkinan lainnya, kesimpulan itu belum tentu berlaku pada level lokal. Setidaknya pada level lokal, mungkin muncul sebuah variasi, yaitu di wilayah-wilayah tertentu faktor-faktor demografi memiliki peran penting dalam mendefinisikan pilihan politik pemilih dalam pilkada. Variasi itu juga dapat muncul dalam bentuk lain, yakni di daerah yang satu efek faktor demografi terhadap pilihan politik pemilih lebih kuat dibandingkan dengan di daerah-daerah lainnya.

Ilustrasi yang disampaikan pada bagian sebelumnya menunjukkan bahwa di Provinsi Kalimantan dan Provinsi DKI, faktor etnisitas dan agama sangatlah prominen. Secara kualitatif, dua faktor ini dapat menjelaskan bahwa faktor-faktor demografi tersebut bekerja pada tingkat lokal. Yang perlu dilakukan dalam studi-studi selanjutnya adalah spesifikasi model untuk menguji secara empirik efekefek tersebut dalam format tesis yang dapat dioperasionalkan.

Implikasi normatif dari berbagai kasus pilkada yang telah digambarkan sebelumnya juga tidak kalah penting: sejauh mana aktivasi isu-isu demografis yang memuat warna primordial menunjukkan kualitas praktik demokrasi di tingkat lokal. Dua mekanisme kausal yang menghubungkan faktor demografis dengan preferensi politik pemilih dikanalisasi dalam dua jenis kampanye. Kampanye jenis pertama menghubungkan publik pemilih melalui isu-isu simbolis, sedangkan kampanye kedua menghubungkan publik pemilih dan preferensi politik melalui isu-isu kebijakan. Isu kebijakan yang ditawarkan oleh para kandidat di atas kertas dapat beresonansi dengan kepentingan kolektif kelompok-kelompok sosial yang menjadi target kampanye. Dengan demikian, mobilisasi melalui kampanye berpotensi untuk menghasilkan pemilih yang kurang lebih rasional.

Idealnya, jenis kampanye kedualah yang secara normatif dan etis dianggap lebih superior. Oleh karena itu, harapan etis yang dapat dituntut kepada para kandidat adalah kemauan mereka untuk bergerak 
melampui penggunaan isu-isu simbolik yang memobilisasi sentimen primordial pemilih ke isu-isu kebijakan yang menghidupkan rasionalitas pemilih. Dalam literatur voting behavior, aktivasi isu-isu kepentingan kolektif ini akan menghasilkan bloc voting (Dalton, 2013). Problem pokoknya adalah ambisi untuk memenangi pemilu kadang mengalahkan dan mematikan tumbuhnya kebajikan normatif untuk jangka panjang. Kenyataan keras di gelanggang-gelanggang pilkada juga mengabarkan bahwa sebagian besar pemilih justru lebih mudah dan lebih tercekam dengan isu-isu primordial. Akibatnya adalah logika politik kalah-menang lebih dominan muncul di kalangan kandidat ketimbang panduan normatif tentang cara mobilisasi pemilih dan pendukung yang lebih ideal. ${ }^{22}$ Untuk situasi ini, harapan etis itu sangat tergantung pada kemunculan principled leaders di tingkat lokal yang secara personal memiliki standar normatif tentang kampanye yang etis dan politis. Selain itu, dalam jangka panjang, harapan itu juga tergantung dari perkembangan kualitas pemilih. Pertumbuhan jenis pemilih yang rasional akan mendorong pemakaian teknik mobilisasi yang berbasis kebijakan. Sebaliknya, pertumbuhan lambat jumlah pemilih rasional di tingkat lokal juga menghambat meluasnya teknik mobilisasi jenis ini dan kampanye yang digulirkan adalah issue-based campaign - kampanye yang memasarkan dari isu-isu kebijakan yang ditujukan pada kelompok-kelompok sosial yang memiliki kepentingan kolektif.

Isu terakhir yang perlu disinggung di sini adalah kehadiran model analisis postdemographics yang kini merebak untuk tujuan pemetaan politik dan perancangan strategi elektoral sejalan dengan terjadinya revolusi digital dan revolusi media sosial yang

\footnotetext{
22 Belajar dari pengalaman personal sebagai surveyor, harapan ini kadang tampak terlalu tinggi. Sering terjadi, meskipun data survei memuat informasi tentang kepedulian publik terhadap permasalah sosial yang penting untuk dijawab melalui kebijakan, para kandidat lebih sering mengabaikan kepedulian publik tentang masalah kemasyarakatan yang menuntut sebuah kebijakan untuk penyelesaiannya.
}

merasuk juga ke gelanggang politik. Logika dasar dari analisis ini tidak berbeda dengan analisis demografis, yakni mengorganisasikan individu yang memiliki atribut sama ke dalam kelompok yang sama pula. Hanya saja, sesuai dengan labelnya, basis pengelompokan individu tersebut tidak berdasar parameter demografis, tetapi berdasar parameter yang berkembang di dunia digital, khususnya di jagat media sosial. Pengelompokan itu bertolak dari kesamaan hobi, buku favorit, film favorit, selera atau gaya hidup, atau rekaman pencarian informasi yang kemudian datadata ini dapat diekstrasikan dari profil para pengguna media sosial dan preferensi politik mereka diekstraksikan dari status (Facebook) dan cuitan (Twitter) mereka, serta dari percakapan yang muncul di berbagai aplikasi media sosial lainnya. ${ }^{23}$

Melalui mesin pelacak yang berbasis algoritma, periset mengoleksi data digital dalam volume raksasa. Analisis yang dilakukan terhadap percakapan ini lazimnya dikategorikan ke dalam percakapan yang bernada positif dan negatif diperlakukan sebagai proksi untuk menebak preferensi politik para pengguna media sosial. Percakapan positif diartikan sebagai dukungan suara, sedangkan yang negatif adalah sebaliknya. Dengan cara ini, preferensi politik dapat diperkirakan atau diprediksi, termasuk dalam pilkada. ${ }^{24}$ Untuk keperluan strategi elektoral, kombinasi data digital profiling para periset dapat merancang pesan kampanye digital untuk kelompok-kelompok yang spesifik. Dari kacamata para kandidat,

\footnotetext{
23 Untuk sebuah paparan ringkas tentang postdemografi ini, lihat, Richard Rogers (2009) "Postdemocraphic machines", In A. Dekker, \& A. Wolfsberger (Eds.), Walled garden. (pp. 29-39). [Amsterdam]: Virtueel Platform.

24 Laporan utama Majalah Tempo tentang Hoax pada edisi 2-8 Januari dapat dijadikan sebagian ilustrasi analisis post-demographics. Dalam infografis selebar dua halaman, Tempo menyajikan tren conversation yang bernada positif dan negatif di Twitter dalam rentang waktu sebulan. Jumlah cuitan yang dianalisis mencapai 50.936 cuitan. Dari jumlah ini, mayoritas percakapan atau sebanyak 44.546 bernada negatif, dan sisanya sebanyak 6.390 percakapan bernada positif.
} 
riset-riset dan analisis post-demographics ini dapat dimanfaatkan untuk merancang strategi kampanye dan mengeksekusinya. Di tengah tren mutakhir yang terus berkembang ini, pemetaan politik yang berbasis demografi mendapatkan saingan baru dalam merebut klien di pilkada-pilkada di masa mendatang. Kelak dapat saja terjadi analisis demografis semakin surut relevansinya dalam pilkadapilkada.

Namun, yang perlu dicatat, tidak peduli apakah pemetaan politik memakai model demografis atau post-demographics, kenyataan di lapangan tidaklah selalu mengikuti imbauan etis atau normatif yang didedahkan para pejabat dan akademisi. Praktik kualitas demokrasi justru banyak ditentukan dalam pertempuran di gelanggang riil pilkada.

\section{Daftar Pustaka}

Andarningtyas Natisha. 2012. "Foke kampanye di Kuningan Barat" (14 September 2012), http://www.antaranews. com/berita/333023/foke-kampanye-dikuningan-barat.

Anderson, Terry. 2005. The Pursuit of Fairness: A History of Affirmative Action. New York: Oxford University Press.

Badan Pusat Statistik. 2010. Penduduk Indonesia Hasil SP 2010. Jakarta: Badan Pusat Statistik.

Badan Pusat Statistik (BPS). 2010. "Metodologi", https://www.bps.go.id/ KegiatanLain/view/id/127.

Badan Pusat Statistik. 2015. Statistik Mobilitas Penduduk 2015. Jakarta: Badan Pusat Statistik.

Barley, Tasa Nugraza. 2016. "The rise of the Indonesian conservatives" (14 December 2016), http://www.rappler. com/world/regions/asia-pacific/indonesia/ english/155485-conservatives-muslimsahok-opinion.
BBC. 2013. "KPU tunda penetapan Daftar Pemilih Tetap" (23 Oktober 2013), http://www.bbc.com/indonesia/berita indonesia/2013/10/131023_kpu_tunda_ penetapan_dpt.

Beritasatu. 2012. "Lagi, Isu SARA Diangkat Supaya Dukung Foke (13 Agustus 2012)", http://www.beritasatu.com/ megapolitan/65942-lagi-isu-sara-diangkatsupaya-dukung-foke.html.

Burton, Michael and Daniel Shea. 2010. Campaign Craft: The Stretgies, Tactics, and Art of Political Management. Santa Barbara, California: Praeger. (4 ${ }^{\text {th }}$ edition).

Dalton, Russell. 2013. Citizen Politics: Public Opinion and Political Parties in Advanced Industrial Democracies. Los Angeles: CQ Press

Economist, The. 2014. "A census in Myanmar: Too much information", 22 March 2014, http://www.economist.com/news/ asia/21599404-ill-considered-headcountstirs-anger-and-mistrust-too-muchinformation.

Faiz. Pan Mohamad. 2016. "Dimensions of Judicial Activism in the Constitutional Decisions," di Jurnal Konstitusi, Volume 13, No. 2, 2016.

Firdaus, Febriana. 2015. "35 calon kepala daerah perempuan menang di Pilkada 2015" (December 10, 2015), http:// www.rappler.com/indonesia/115543perempuan-menang-di-pilkada-2015.

Fox, Colm and Jeremy Menchik. 2011. "The Politics of Identity in Indonesia: Results from Campaign Advertisements". APSA 2011 Annual Meeting Paper. Available at SSRN: https://ssrn.com/abstract $=1901782$

Haluan Lampung. 2016. "Parosil Mabsus Serahkan Berkas" (18 Februari 2016), http://www.haluanlampung.com/index.php/ politik/10507-parosil-mabsus-serahkanberkas.

Populasi Volume 24 Nomor 22016 
Harian Fokus. 2016. "PKB Target Wakil di Pilkada Tubabar", (8 Mei 2016), https:// www.harianfokus.com/2016/05/08/pkbtarget-wakil-di-pilkada-tubabar/.

Harian Lampung. 2016. "Golkar Usung Tiga Petahana pada Pilkada 2017" (5 Februari 2016), http://harianlampung.com/index. php?k=politik\&i=20151-golkar-usung-tigapetahana-pada-pilkada-2017.

Harjono Yulvianus dan Fajar Marta. 2010. "Putra Daerah dan Aristokrasi Politik" (29 Oktober), http://bisniskeuangan.kompas. com/read/2010/10/29/03123960/putra. daerah.dan.aristokrasi.politik.

Hukum Online. 2009, "Kisruh DPT, Noda Tercecer di Pemilu 2009" (31 Desember 2009), http://www.hukumonline.com/ berita/baca/lt4b3c5d4990d94/kisruh-dptnoda-tercecer-di-pemilu-2009.

Hukum Online. "Apakah Calon Kepala Daerah Harus Putra Asli Daerah Pemilihan?", (6 April 2012) http://www.hukumonline.com/ klinik/detail/lt4f7b13d0c46aa/apakahcalon-kepala-daerah-harus-putra-aslidaerah-pemilihan-.

Indikator Politik Indonesia. 2015. "Laporan Survei untuk Provinsi Kalimantan Utara (Kaltara), Bulan Mei 2015.

Indikator Politik Indonesia. 2015. "Laporan Survei Pilkada untuk Kota Bontang," Bulan Mei 2015.

Indikator Politik Indonesia. 2015. "Laporan Survei untuk Pilkada Kabupaten Malinau," Bulan Mei 2015.

Jafar. 2010. "Isu Putra Daerah dalam Pilkada Koyak Kebangsaan" (14 Maret 2010), http:// www.antaranews.com/berita/177697/ isu-putra-daerah-dalam-pilkada-koyakkebangsaan.

JPNN. 2016. (13 Februari 2016), "Kakak Andi Arief Siap Maju”, http://www.jpnn.com/ news/kakak-andi-arief-siap-maju.

Kertzer, David and Dominique Arel (eds). Census and Identity: The Politics of
Race, Ethnicity and Language in National Censuses. New York: Camridge University Press.

Kompas. 2009. "Puluhan Ribu DPT Bermasalah di Jateng" (1 April 2009), http://nasional. kompas.com/read/2009/04/01/20572617/ puluhan.ribu.dpt.bermasalah.di.jateng.

Kompas. 2015. "Selisih Tipis, Hasil Pilkada di 13 Daerah Berpotensi Sengketa" (15 Desember 2015), http://nasional. kompas.com/read/2015/12/15/17023981/ Selisih.Tipis.Hasil.Pilkada.di.13.Daerah. Berpotensi.Sengketa.

Koran Tempo. 2009. "Daftar Pemilih Bermasalah di 15 Provinsi" (6 Maret 2009), https://koran.tempo.co/ konten/2009/06/03/166937/DaftarPemilih-Bermasalah-di-15-Provinsi.

Kusumadewi, Anggi dan Desy Afrianti. 2012. "Jelang Putaran Kedua, Foke vs Jokowi Memanas", 10 Agustus 2012, http:// fokus.news.viva.co.id/news/read/343144pertarungan-pilkada-dki-putaran-iimemanas.

Lembaga Survei Indonesia. 2012. Laporan Survei "Pilkada DKI Jakarta, Protes Kelas Menengah". Laporan Survei, 2-7 September 2012.

Lembaga Survei Indonesia. 2016. Laporan Survei "Pilkada Jakarta Likeability is Electability?” Desember 2016.

Muhiddin, Abdul Hakim. 2010. "'Asli Urang Banua' Dongkrak Suara” (4 Juni 2010), http://www.antarakalsel.com/berita/88/asliurang-banua-dongkrak-suara.

Mujani, Saiful, R. William Liddle, Kuskridho Ambardi. 2012. Kuasa Rakyat: Analisis tentang Perilaku Memilih dalam Pemilihan Legislatif dan Presiden Indonesia pascaOrde Baru. Bandung: Mizan.

Okezone. 2015. “Transmigran Minta Paslon Peserta Pilkada Kabupaten Jayapura Tak Umbar Janji” (25 Oktober 2015), http://news.okezone. 
$\mathrm{com} / \mathrm{read} / 2016 / 10 / 25 / 340 / 1523611 /$ transmigran-minta-paslon-pesertapilkada-kabupaten-jayapura-tak-umbarjanji.

Otto, Ben and Anita Rachman. 2016. "HardLine Strain of Islam Gains Ground in Indonesia, World's LargestMuslimCountry", http://www.wsj.com/articles/hard-linestrain-of-islam-gains-ground-in-worldslargest-muslim-country-1478248172.

Poston Jr, Dudley and Leon Bouvier. 2010. Population and Society: An Introduction to Demography. New York: Camridge University Press.

Perludem. 2016. "Keterlibatan Perempuan di Pilkada Menurun" (30 November 2016), http://perludem.org/2016/11/30/ keterlibatan-perempuan-di-pilkadamenurun/.

Petit, Veronique. 2013. Counting Population, Understanding Society: Toward an Interpretative Demography. New York: Springer.

Riau Terkini. 2015. "Pilkada Kuansing, Warga eks Transmigran Yaman dengan Kepemimpinan MH" (20 Oktober 2015), http://www.riauterkini.com/politik. php? arr $=99404 \&$ judul=Pilkada\% 20 Kuansing, $\% 20$ Warga $\% 20$ eks $\% 20$ Transmigran\%20Yaman\%20dengan $\% 20$ Kepemimpinan\%20MH.

Ribar, Matthew. 2015. "Democracy in Myanmar?" (26 November 2015), http:// foreignaffairsreview.co.uk/2015/11/ democracy-in-myanmar/.

Rogers, Richard. 2009. "Post-democraphic machines". In A. Dekker, \& A. Wolfsberger (Eds.), Walled garden. (pp. 29-39). [Amsterdam]: Virtueel Platform.

Rostanti, Qomarria dan Irwan Ariefyanto. 2012. "Politik Pilkada Jangan Dibawa ke Kawasan Transmigrasi (26 November 2012), http://www.republika.co.id/berita/ nasional/politik/12/11/26/me3hcn-politikpilkada-jangan-dibawa-ke-kawasantransmigrasi.

Rustan, Mario. 2015. "Rising conservatism in Asia", (5 November 2015), http://www. thejakartapost.com/news/2015/11/05/ rising-conservatism-asia.html.

Sunardi. 2015. "Warga Eks Transmigrasi Diperhatikan" (29 Juli 2015), http:// riaumandiri.co/mobile/detailberita/15858/ warga-eks-transmigrasi-diperhatikan.html.

Tribun News. 2010. "Kisruh DPT di Samalewa" (21 Juni 2010) http://www.tribunnews. com/election/2010/06/21/kisruh-dpt-disamalewa.

Victoria, Widya. 2015. "Pengusaha Tambang Versus Urang Banua” (19 Juli 2015), http:// politik.rmol.co/read/2015/07/19/210463/ Pengusaha-Tambang-Versus-UrangBanua-.

Win, Thin Lei. 2015. "In Burma, Not All Votes Are Created Equal (5 November 2015), http://www.irrawaddy.com/election/feature/ in-burma-not-all-votes-are-created-equal. 